\title{
A democratização das relações internacionais segundo Norberto Bobbio ${ }^{1}$
}

\section{La democratizzazione delle relazioni internazionali secondo Norberto Bobbio}

\author{
Taíza Maria Alves da Silva(*) \\ Recebido em: 08/2016 \\ Aprovado em: 11/2016
}

\begin{abstract}
Resumo Bobbio foi um importante filósofo do direito da contemporaneidade. As suas investigações mais relevantes giram em torno da tríade dos seus ideais: democracia, direitos humanos e paz, com ênfase, sobretudo, para a primeira. O objetivo deste trabalho é demonstrar que, apesar de todas as suas reservas e críticas à democracia, ele a considerava o melhor sistema de governo para as sociedades atuais e possuía uma razoável confiança na sua expansão no futuro. Bobbio, partindo de Kant, rejeita a ideia da república perfeita, mas acredita que a espécie humana caminha para uma constituição civil perfeita, e esta é democrática. Tal análise servirá de base para refletir sobre a perspectiva bobbiana em torno do que ele chama de "democracia dos pósteros" e o que ele concebeu como uma democratização das relações internacionais.

Palavras-chave: Relações internacionais; Bobbio; Democracia.
\end{abstract}

\begin{abstract}
Riassunto: Bobbio è stato un importante filosofo del diritto della contemporaneità. Le sue indagini più rilevanti ruotano attorno alla triade dei suoi ideali: democrazia, i diritti umani e la pace, sottolineando, soprattutto, la prima. L'obiettivo di questo studio è quello di dimostrare che, nonostante tutte le sue riserve e critiche alla democrazia, egli la considerava il miglior sistema di governo per la società attuale e aveva ragionevole fiducia nella sua espansione in futuro. Bobbio, a partire dal pensiero di Kant, rifiuta l'idea della repubblica perfetta, ma ritiene che la specie umana si sta dirigendo verso una costituzione civile perfetta, e questa è democratica. Questa analisi costituirà la base per riflettere sulla prospettiva bobbiana intorno a ciò che egli chiama la "democrazia dei posteri" e che ha concepito come una democratizzazione delle relazioni internazionali.

Parole chiave: relazioni internazionali; Bobbio; Democrazia.
\end{abstract}

\section{Introdução}

A democracia, já foi dito, é um caminho. Mas para onde? Norberto Bobbio

Apesar de nunca ter se considerado propriamente um filósofo, Norberto Bobbio é reconhecido como um dos grandes jusfilósofos contemporâneos. Ele foi um filho do seu século e vivenciou os seus eventos mais marcantes: as duas grandes guerras mundiais, a revolução russa, o fascismo e o nazismo, os regimes totalitários, as bombas atômicas de Hiroshima e Nagasaki, a guerra fria além do terrorismo internacional. Assim, baseou inúmeros dos seus escritos nos temas que são a tríade dos seus ideais: direitos humanos, democracia e paz ${ }^{2}$, sendo estes interdependentes, pois "sem direitos do homem reconhecidos e protegidos, não há democracia; sem democracia, não existem as condições mínimas para a solução pacífica dos conflitos" (BOBBIO, 2004, p. 1). A propósito,

* Doutoranda em Ciências Jurídicas da Universidade do Minho, Braga, Portugal. 
como alerta Lafer (2009b, p. 11), enquanto a contribuição de Bobbio para a teoria da democracia é bem reconhecida, o mesmo não se pode dizer sobre suas análises acerca da paz e da guerra, temáticas estas que ressoam no campo das relações internacionais.

O fato é que diante da diversidade de temas tratados, o conjunto da sua obra suscita a imagem de um grande labirinto, no qual aquele que se propõe a analisá-la corre o risco de perder-se na dispersão dos seus múltiplos caminhos. A proposta do presente artigo é percorrer uma das vias do labirinto bobbiano, privilegiando uma discussão sobre o que ele chamou de "a democracia dos pósteros", ou seja, o que entendia ser um projeto cosmopolita da democracia do futuro.

Numa de suas mais célebres obras, O futuro da democracia ${ }^{3}$, ele condensa com primor o seu trajeto de pensador democrático. Embora buscando não cair nas armadilhas da história profética, ele afirma ter por propósito tecer comentários sobre os regimes democráticos atuais, bem como traçar um prognóstico da democracia do futuro. No texto, a democracia é apresentada sob a égide de argumentos ora a favor, ora contra, sua natureza e constituição, de modo que fica evidente um certo desencanto quanto ao regime de governo que tanto enalteceu. Mas não se trata apenas de mais um texto pessimista sobre a democracia. Neste, Bobbio (2009a, p. 19) afirma que a democracia, conquanto não esteja gozando no mundo de ótima saúde, "como de resto jamais gozou no passado, não está à beira do túmulo". E aqui reside um notável ponto de tensão na sua obra: ele é um crítico severo da democracia, reconhece suas falhas e sinaliza as chamadas "promessas não cumpridas" que se encontram entranhadas no cerne das teorias clássicas da democracia moderna, mas também aponta para os avanços da extensão do seu processo de internacionalização.

O jusfilósofo italiano acreditava que a democracia era a direção na qual deveria avançar e, de fato, estaria avançando a civilização. Ele exprimia sua preferência por um tipo de "pacifismo institucional-jurídico", no qual estaria previsto um Terceiro, acima das partes e legitimado "pelo consenso da grande maioria dos Estados que compõem o sistema internacional". Este poderia prevenir os conflitos ou, caso tais conflitos fossem deflagrados, teria força para limitar suas consequências (BOBBIO, 2003, p. 08).

Mais adiante, entretanto, o próprio Bobbio não alimenta grandes expectativas de que a instituição deste Terceiro seja possível e com certo desapontamento reconhece que as guerras então em curso (1997) demonstravam a insuficiência do pacifismo institucional. Este mesmo pacifismo que, num prefácio da obra $O$ problema da guerra e as vias da paz escrito em 1991, ele afirmava ser o único crível e dirigido contra o próprio Estado. Assim, 
seguindo a linha do pacifismo, Bobbio (2003, p. 47) defende que o método mais convincente e elevado para a solução dos conflitos sociais é a democracia, que permitiu, desde a sua primeira aparição, que "o vencido de ontem torne-se o vencedor de amanhã sine effusione sanguinis". Destarte, ele confirma suas apostas nesta última como a melhor dentre as formas de governo e ressalta a sua importância tanto no âmbito interno dos Estados quanto no âmbito externo, ou seja, no que diz respeito ao seu processo de difusão mundial de uma democracia internacional.

\section{A concepção democrática de Bobbio ${ }^{4}$}

A concepção que Bobbio tem da democracia é bastante clara: ela é moderna, representativa, liberal e procedimental ${ }^{5}$. Porém, tal concepção é marcada por tensões e perpassada por dicotomias, que nem sempre Bobbio resolve ou parece querer resolver. Estas últimas surgem como um recurso metodológico, um instrumento de estruturação do pensamento, e marcam a sua visão dualística do mundo político.

Quanto aos dois primeiros elementos, Bobbio distingue a democracia antiga da moderna por um traço marcante: a democracia dos antigos era direta, e a dos modernos, representativa. Não há como ignorar, entretanto, que entre as duas formas de democracia há uma inversão de perspectiva importante: na modernidade são previstos, como complemento, institutos da participação popular direta e entre os antigos existia um processo bastante semelhante ao eleitoral (a eleição dos magistrados), mas que não se configurava como o modelo preponderante. Assim, "enquanto atualmente a eleição é a regra e a participação direta a exceção, antigamente a regra era a participação direta, e a eleição, a exceção" (BOBBIO, 2000, p. 374).

Quanto ao terceiro elemento vale destacar algumas considerações. Além de a sua formação intelectual possuir forte embasamento liberal, a ponto de ser esta uma postura que prevalecerá em diversos dos seus ensaios, a democracia moderna desenvolveu-se em meio ao embate entre o liberalismo e o socialismo, e Bobbio fará incursões nas duas doutrinas políticas ${ }^{6}$. Importante considerar, ainda, que o liberalismo bobbiano não finca suas raízes no mercado livre ou em questões puramente econômicas: trata-se do liberalismo político ${ }^{7}$, comprometido, sobretudo, com o Estado constitucional. Assim, falar em liberalismo neste contexto implica numa concepção de que este "tem poderes e funções limitadas", e como tal se contrapõe ao Estado absoluto e ao Estado social (BOBBIO, 2005, p. 7). Quanto à sua justificação racional, o Estado liberal nasceu como resultado do acordo entre os indivíduos livres que convencionaram 
os vínculos necessários a uma convivência pacífica e duradoura. E quanto ao seu pressuposto filosófico, este reside na doutrina dos direitos do homem. Tais direitos devem ser respeitados pelo Estado ou por quem detenha o poder legítimo. Ao admitir que o termo "liberalismo" conheceu diversos significados, Bobbio (2000) o define, embasado em von Hayek, como uma "teoria dos limites do poder do Estado" que valem, enquanto limites, inclusive para um regime democrático. Há, portanto, o que Bobbio (2005, p. 45) chama de "nexo recíproco entre liberalismo e democracia", pois ambos têm o indivíduo como ponto de partida.

Quanto ao último elemento, é possível observar duas possibilidades teóricas: na primeira vê-se uma concepção ética da democracia (textos dos anos de 1940) e uma segunda, que traz a democracia enquanto procedimento, e vai marcar a obra de Bobbio a partir da década de 1950. Segundo a concepção ética, a democracia é uma forma de governo portadora de um determinado fim, que deverá ser alcançado através dela, enquanto que, de acordo com a concepção procedimental, privilegia-se o meio e não o fim, sendo a democracia é um método para a tomada das decisões, desprovida de finalidade e não exigindo nenhum conteúdo para as citadas decisões (BRANDÃO, 2011) ${ }^{8}$.

Deste modo, embora tanto a percepção ética quanto a procedimental esteja presente na sua concepção de democracia, Bobbio foi reconhecido como adepto desta última. Destarte, parece-me que Bobbio de fato opta por esta concepção procedimental, embora não abandone por completo a sua concepção ética. Tanto o é que o próprio Bobbio (2001) declara que a democracia almejada deve ser sentida como um valor, uma finalidade e não um simples instrumento.

Neste sentido, Bobbio (2009a, p. 30) refere-se à construção de uma definição mínima de democracia como "um conjunto de regras (primárias ou fundamentais) que estabelecem quem está autorizado a tomar as decisões coletivas e com quais procedimentos". Para que uma decisão adotada por alguns indivíduos seja aceita como decisão coletiva é imprescindível que ela seja tomada com base em regras e procedimentos. Mas isso não basta, porque, além de garantir o direito de participação a um elevado número de cidadãos e de defender a existência de regras e procedimentos, ele acrescenta uma terceira condição, "é preciso que aqueles que são chamados a decidir ou eleger os que deverão decidir sejam colocados diante de alternativas reais e postos em condição de escolher entre uma e outra"” (BOBBIO, 2009a, p. 32).

Assim, embora Bobbio (2004) afirme, ao pensar sobre o futuro da humanidade, ser cada vez maior a proclamação de direitos, ao mesmo tempo em que é cada vez mais escassa a sua efetividade ${ }^{10}$, este aparente paradoxo não invalida a sua confiança na democracia. Na verdade, ele entende que este é um regime que tem se adaptado às mudanças naturais da sociedade, de forma 
que pelo menos até os dias atuais parece estar cumprindo bem o seu papel.

Neste sentido, e inspirando-se em Kant, Bobbio afirma que o atual debate sobre os direitos do homem pode até mesmo ser interpretado como um sinal premonitório (signum prognosticum) do progresso moral da humanidade, embora advirta que "um sinal premonitório não é ainda uma prova. É apenas um motivo para que não permaneçamos espectadores passivos" (BOBBIO, 2004, p. 149). Assim, quando reflete sobre os caminhos da paz internacional, Bobbio se inspira nos clássicos, e se vale, sobretudo, de Kant e seu Projeto da Paz Perpétua (LAFER, 2009B). Em mais de uma obra ele trata do processo de democratização das relações internacionais, ao qual se pode mencionar como sendo o projeto cosmopolita de Bobbio para a democracia do futuro.

\section{A democracia dos pósteros}

"Kant não é em absoluto um escritor democrático". Esta foi uma constatação que Bobbio (2000, p. 106-107) apresentou quando, ao tratar da fórmula do contrato originário do filósofo prussiano, afirmou que tal fundamento do Estado não era um fato histórico, mas uma pura ideia reguladora, "uma simples ideia da razão, mas que sem dúvida tem a sua realidade (prática)". Como bem o disse Lafer (2009b, p. 65) a análise de Kant do sistema internacional é elaborada de uma perspectiva universalista e quando Bobbio, nos seus textos, tratava do âmbito internacional, a sua vis directiva filosófica "é o Kant do Projeto de Paz Perpétua, ou seja, a paz como um ditame da razão, capaz de lidar com a 'insociável sociabilidade humana'. Esta vis diretiva, no entanto, é permeada pelo realismo de um olhar hobbesiano". E conclui que "Bobbio, kantianamente, tem muita consciência que o progresso humano não é necessário. É apenas possível" (LAFER, 2009b, p. 14).

Assim sendo, entendo que Bobbio quando delineou sua análise dos sistemas democráticos estava, de fato, partindo da democracia enquanto ideia. De modo que, ao considerar que a democracia não se realizou nos moldes ideais, sua análise apontava que a democracia tinha sim um futuro, mas este era diferente do que projetaram os pensadores clássicos. Daí a sua convicção que a nossa civilização avança no sentido da democracia, embora a aplicação das suas regras nunca tenha sido perfeita e a democracia real seja apenas uma pálida aproximação da ideal (BOBBIO, 2009b).

Do mesmo modo, Bobbio reflete sobre a democracia como ideia ${ }^{11}$ - no sentido kantiano do termo - ou seja, de um conceito racional, de uma perfeição que, apesar de todos os obstáculos que atrapalhem a sua realização, é possível, embora não tenha, ainda, sido plenamente efetivado na experiência. Ou seja, o 
termo ideia no pensamento de Kant trata-se de um conceito que não pode ser encontrado em parte alguma da experiência (CAYGILL, 2000), porque para Kant, a ideia se mostra como reguladora, e não como constitutiva do conhecimento (SALGADO, 1986).

Ideias são conceitos da razão, aos quais nenhum objeto pode ser adequadamente dado na experiência [...] são conceitos de uma perfeição, de que o homem se aproxima sempre, mas não pode nunca alcançar completamente (KANT apud TERRA, 1995, p. 25).

Ao tratar da democracia no seu ensaio A era dos direitos, Bobbio (2004, p. 60) retoma a discussão entre o ideal e o real dos direitos do homem, afirmando que "poder-se-iam multiplicar os exemplos de contraste entre as declarações solenes e sua consecução, entre a grandiosidade das promessas e a miséria das realizações". Ao mesmo tempo considera que a crescente importância atribuída nos debates internacionais acerca do problema do reconhecimento dos direitos do homem é um sinal premonitório do progresso moral da humanidade. Todavia, este progresso deveria ser mensurado pelos fatos, e não somente pelas boas intenções e palavras. Nesta perspectiva, os direitos do homem estão inevitavelmente ligados à questão da paz e da democracia. Daí ter afirmado, acerca do nexo inevitável entre a democracia e a paz, que "o futuro da paz está estreitamente conectado com o futuro da democracia" (BOBBIO, 2009b, p. 54) e, ainda, que a defesa dos direitos humanos no interior de cada Estado é um pressuposto do processo de democratização do sistema internacional (BOBBIO, 2009b, p. 55).

Bobbio (2004, p. 203) afirmava estar cada vez mais convencido de que o ideal da paz perpétua só poderia ser perseguido "através de uma democratização progressiva do sistema internacional", que deveria ocorrer simultaneamente à proteção efetiva dos direitos do homem, mesmo que acima dos seus próprios Estados. Destarte, o "futuro da democracia" não se resume somente ao avanço do processo de democratização das relações internacionais. É preciso, ainda, o aumento do número de Estados democráticos. Segundo Bobbio (2009a, p. 13), o sistema ideal da paz estável pode ser expresso pela fórmula: "uma ordem democrática de Estados democráticos", mas ele alerta que assim como o são todas as fórmulas ideais, esta não pertence a esfera do ser, mas sim do dever ser.

Aqui se percebe o retorno a uma tradição milenar, que ainda ocupa um lugar no campo de discussão das relações internacionais: o cosmopolitismo. Este teve seus primeiros esboços formulados pelos estoicos, na Grécia helenística. Segundo estes, o cosmos poderia ser compreendido como a polis universal, de modo que o homem, pelo fato de ser homem, poderia se sentir em 
casa onde quer que estivesse. Daí surgiu a expressão kosmou polites (cidadão do mundo), atribuída a Diógenes de Sinope.

A tradição do cosmopolitismo repercutiu igualmente nas instituições romanas, tendo sua primeira elaboração jurídica no ius gentium (direito que regulava os povos segundo a Pax Romana). Já na Idade Média, o cosmopolitismo passa a ter influência na res publica christiana, que também lhe dará uma feição jurídica ao enunciar regras que deveriam ser respeitadas nas relações entre os povos. E, embora o cosmopolitismo tenha recebido atenção de grandes teóricos iluministas como o Abade de Saint-Pierre (Projeto para tornar perpétua a paz na Europa) e Rousseau (Rousseau e as relações internacionais), é na obra de Kant que o projeto cosmopolita vai firmar sua contribuição moderna mais importante. Será ele, com efeito, que vai introduzir no direito internacional uma terceira dimensão: o direito cosmopolita (MELO, 2010). Assim, entendo ser essencial, numa reflexão sobre o porvir da democracia, que se pense também sobre o cosmopolitismo.

Bobbio (2003, p. 49-50) cita três metáforas intrigantes para ilustrar os modos de conceber o sentido da história e que podem ser aplicadas ao problema "do sentido ou do destino da humanidade". A primeira é de Wittgenstein que afirmava ser a tarefa da filosofia ensinar a mosca a sair da garrafa. Esta seria uma situação que explicita haver sempre uma via de saída, mas que não está imediatamente perceptível para quem se encontra na circunstância. O filósofo está fora da garrafa e, como espectador, "vê claramente onde está".

A segunda metáfora é a do peixe na rede. Este tenta sair, e para tal se debate, porque acredita que há uma saída, mas esta não existe. "Quando a rede for aberta (não por ele), a saída não será uma libertação, isto é, um princípio, mas a morte, ou seja, o fim". A constatação de Bobbio (2003, p. 50) é de que a tarefa do filósofo, do espectador externo que vê não apenas o esforço, mas também o objetivo, não pode mais ser aquela descrita por Wittgenstein, que muito provavelmente ele pregará a inutilidade da agitação sem finalidade. Entretanto, talvez a condição humana não esteja representada em nenhuma destas duas metáforas, mas numa terceira: a de um labirinto em que há saída, mas não sabemos exatamente onde ele está, porque "não há nenhum espectador de fora que conheça preventivamente o percurso. Estamos todos dentro da garrafa". Para sair se deve avançar tateando, por tentativas, avanços, recuos, sucessivas aproximações, paciência porque "às vezes a via que parece mais fácil não é a mais correta; outras vezes, quando acredita estar mais próximo da meta, está mais longe, e basta um passo em falso para voltar ao ponto de partida" (BOBBIO, 2003, p. 50).

Nesta última metáfora, a tarefa do filósofo é bem mais modesta se comparada à primeira (da mosca na garrafa), e bem menos sublime se 
comparada à segunda (dos peixes na rede). A metáfora do labirinto caracteriza a situação em que "nenhuma saída está absolutamente assegurada e, quando o caminho está certo, isto é, quando leva a uma saída, nunca é a saída final" de forma que a lição dada pela experiência ao homem que percorre o labirinto "é que existem caminhos sem saída: a única lição do labirinto é a lição do caminho bloqueado" (BOBBIO, 2003, p. 51). Numa metáfora aproximativa ${ }^{12}$ Bobbio (2003, p. 47) considera que a guerra é uma destas vias bloqueadas, sendo a democracia "o exemplo mais elevado e mais convincente do método nãoviolento para a solução de conflitos sociais".

Nesta linha de pensamento, a democracia, desde o seu surgimento, procurou substituir "o corpo a corpo pela discussão, o golpe de misericórdia do vencedor sobre o vencido pelo voto e a vontade da maioria, que permitem ao vencido de ontem tornar-se o vencedor de amanhã sine effusione sanguinis". O aumento do número de Estados democráticos, além da expansão dessa democratização em nível mundial, é um caminho que Bobbio aponta para a paz estável. Mas o que Bobbio entendia por paz?

Entendo por paz um estado de não-guerra, compreendida a guerra como "embate
violento, contínuo e duradouro entre grupos organizados". Uma definição desse tipo
abrange tanto as guerras internacionais quanto as guerras civis ou internas, nelas
incluída, no limite, a guerrilha, que é em parte interna e externa (BOBBIO, 2009b,
p.241).

No tocante ao futuro da humanidade, Bobbio parte do pensamento de Kant, todavia se contrapõe a este num ponto extremamente relevante: Kant afirmava que o futuro da humanidade seria uma república perfeita, posto que não compreendia a democracia como representativa da vontade geral nem um caminho para a paz perpétua. Bobbio se contrapõe a essa ideia de república perfeita kantiana, embora parta do mesmo Kant para formular sua própria concepção. Para Bobbio, o futuro da humanidade é uma democracia perfeita, isto é, uma democracia internacional e não uma república como pensava Kant ${ }^{13}$.

No "Primeiro Artigo Definitivo para a Paz Perpétua", Kant (1989) afirma que das três formas de Estado, a democracia funda um poder executivo em que todos decidem sobre e, em todo o caso, também contra um (que, por conseguinte, não dá o seu consentimento), portanto, "todos, sem, no entanto, serem todos, decidem". Para Kant (1989, p. 70), vê-se aí "uma contradição da vontade geral consigo mesma e com a liberdade".

Kant chama de forma republicana aquela em que vigora o princípio da separação dos poderes, mesmo se o titular do poder de governo é um monarca. De tal modo, "república" adquire um novo significado, que não é mais o de Estado geral, e nem mesmo é mais o de governo de assembleia contraposto ao governo de um só, mas é o de uma forma de governo que tem uma certa estrutura interna, compatível inclusive 
com a existência de um rei (BOBBIO, 1987, p. 108).

Bobbio, embora partindo de Kant, rejeita a ideia da república perfeita, mas acredita que a espécie humana ainda caminha para uma constituição civil perfeita, só que esta é democrática. Assim, ele acredita na humanidade sob a égide da democracia. Deste modo, a democracia não há de ser descartada, sendo marcante em Bobbio este ponto de distinção da proposta kantiana, ou seja, ele defende uma "democracia perfeita" para o futuro da humanidade. Essa república que Kant defendia, de acordo com sua tese, levaria a uma constituição civil perfeita.

Esse adjetivo "perfeita" é de suma importância porque dá a constituição civil a condição de ideia da razão pura. Em A Era dos Direitos (2004), Bobbio chama a atenção para a necessidade de ter que dar uma resposta ao problema da humanidade, ou do destino desta. Então observa que ninguém mais o faz na atualidade, nem o historiador, o geógrafo, o economista. Ninguém se arvora a responder a questão, nem mesmo os filósofos. Mas ele precisa fazer isso. E o faz recorrendo a uma categoria que foi criticada por Hegel, qual seja, a filosofia da história kantiana ${ }^{14}$. Mas são muitos os pensadores da filosofia da história. Se para Kant o futuro da humanidade está numa república internacional, para Bobbio parece mais plausível apostar numa democracia internacional.

Quanto ao progresso ${ }^{15}$ afirmado por Kant, ele estaria presente no contínuo movimento da democracia frente às barreiras que aparecem. Em outras palavras, enquanto em Kant o modelo ideal de Estado seria a república, para Bobbio este seria a democracia, de forma que ele se pergunta: "Será que estava certo Kant quando proclamou como primeiro artigo definitivo de um possível acordo pela paz perpétua que 'a constituição de cada estado deve ser republicana'?" (BOBBIO, 2009a, p. 50). Bobbio, apesar das diferenças evidenciadas, chama de democracia uma atualização para os tempos modernos da república de Kant, ou seja, uma concepção ampliada de república que inclua as massas populares, dentro dos limites impostos pelas regras do jogo.

Refletindo sobre os grandes ideais, e analisando as democracias no âmbito interno dos Estados, Bobbio foi além desta esfera e elaborou algumas importantes reflexões a respeito da democratização internacional. Assim, o futuro da democracia não implica apenas na ampliação do número de Estados democráticos, mas também que o desenvolvimento e a extensão do processo de democratização alcancem as relações internacionais. Nesta sua análise, Bobbio aponta para a construção de um ideal muito significativo no seu pensamento: o ideal da solução pacífica dos conflitos entre os Estados, ao qual chamaremos somente de ideal da não-violência. Deste modo, em textos posteriores a "O futuro da democracia" Bobbio cumpre o seu intento de pensar na democracia dos pósteros com maior profundidade, refletindo sobre sua 
difusão em nível mundial.

Ocorre que, para refletir sobre a possibilidade de difusão da democracia em nível internacional, não é suficiente ter por único parâmetro a democracia no âmbito interno dos Estados. A relação entre um Estado e seus cidadãos é diversa daquela que este mesmo Estado teria com outros Estados igualmente soberanos. Não há como se importar um modelo como se esta democracia internacional fosse simplesmente uma democracia interna "aumentada". Afinal, se Bobbio reconhece que a democracia real (analisada no interior dos Estados) não se efetivou em todos os seus termos, como se pode refletir somente através desta democracia interna no que diz respeito ao processo de internacionalização da democracia?

[...] é difícil e - posso dizer sem correr o risco de ser julgado um pessimista irredutível - irrealista aplicar ao sistema dos Estados procedimentos e medidas que valem dentro de cada Estado particular nas relações entre os poderes públicos e o cidadão. Cada Estado detém em relação aos seus cidadãos o monopólio da força legítima, um poder que jamais existiu, que não existe atualmente e que provavelmente jamais poderá existir no futuro, dentro do sistema internacional (BOBBIO, 2003, p. 14).

Um outro ponto também merece cautela nesta discussão sobre a democracia do futuro: pode-se falar em democratização internacional sem que seja semeado simultaneamente o ideal de paz universal? Bobbio (2009b, p. 242) alerta que enquanto para os projetos de paz perpétua elaborados a partir do século XVIII, e dos quais o mais célebre é o de Kant, a paz universal significava a paz entre as potências europeias, "hoje é inevitável que se compreenda por paz a eliminação da relação de guerra entre todos os Estados do mundo, o que, como os senhores compreendem, complica terrivelmente o problema".

No tratado imaginário, escrito em 1795/96 e intitulado "Para a paz perpétua", Kant faz menção a três condições para a paz mundial: na primeira, afirma que a Constituição de todo Estado deve ser republicana, e pertence ao direito público interno, de modo que todo indivíduo possa exercer sua liberdade no respeito da liberdade do outro; na segunda, afirma que o direito internacional (o direito das gentes) deve se fundar numa Federação de Estados livres; e, na terceira, apresenta um diferencial interessante quando pondera que devem ser consideradas as relações entre os Estados e "também as relações entre cada Estado particular e os cidadãos dos outros Estados, ou, inversamente, entre o cidadão de um Estado e um Estado que não é o seu com os outros Estados" (BOBBIO, 2004, p. 126). Quando trata deste direito de visita do cidadão estrangeiro e do dever de hospitalidade do Estado visitado, ou seja, destas condições de hospitalidade universal, Kant prefigurou "o direito de todo homem a ser cidadão não só do seu próprio Estado, mas do mundo inteiro; além disso, havia representado toda a Terra como uma potencial cidade do mundo, 
precisamente como uma cosmópolis" (BOBBIO, 2004, p. 127).

Bobbio (2004, p. 127) constata, assim, que a Declaração Universal "colocou as premissas para transformação também dos indivíduos singulares, e não mais apenas dos Estados, em sujeitos jurídicos do direito internacional" e indaga-se se "essa nova fase do direito internacional não poderia ser chamada, em nome de Kant, de direito cosmopolita?" As raízes deste entendimento bobbiano podem estar também em Ideia de uma história universal com um propósito cosmopolita [1784], texto no qual Kant enunciava sua esperança que o curso regular da natureza poderia conduzir, após muitas revoluções transformadoras, a "um Estado de cidadania mundial como o seio em que se desenvolverão toas as disposições originárias do gênero humano" (KANT, 2009, p. 35). O cosmopolitismo kantiano constitui uma teoria que defende uma tendência do aperfeiçoamento moral da humanidade. Quando Kant revisita a ideia estóica do cosmopolitismo em A paz perpétua [1795], ele propõe um projeto filosófico que possibilitaria um estado de paz perpétua através de um pacto consagrado entre os povos. Tal acordo não seria apenas a extinção de uma, mas sim de todas as guerras (MELO, 2010). Considerando que o debate contemporâneo sobre o processo de globalização, bem como a barbárie e a violência das duas grandes guerras do século $X X^{16}$, trouxeram de volta ao centro da discussão o cosmopolitismo, é nesta perspectiva que Bobbio afirma estar cada vez mais convencido de que o ideal da paz perpétua só pode ser perseguido através de uma democratização progressiva do sistema internacional.

\section{A democratização das relações internacionais}

O último texto da obra O futuro da democracia é o ensaio Democracia e sistema internacional, publicado em 1989 no volume Democrazia, rischio nucleare, movimenti per la pace. Neste, Bobbio (2009a, p. 188) afirma ter se ocupado muito nos últimos anos com as duas grandes dicotomias da teoria geral da política: democracia-autocracia, paz-guerra, tanto que ele indaga se seria possível "um sistema democrático internacional entre Estados autocráticos" e "um sistema autocrático internacional entre Estados democráticos". Em suma, ele questiona "se é possível ser democrático em um universo não-democrático".

Inicialmente é preciso considerar que os Estados coexistem num universo composto por outros tanto, convivendo no que Bobbio chama de "sociedade de Estados" que estabelecem entre si alguns limites de convivência. Tais limites podem ser de fato ou ainda limites jurídicos nos moldes impostos "pelo direito que regula - desde tempos imemoriáveis - as relações entre Estados soberanos, ou ius gentium, limites que derivam de tradições tornadas vinculatórias (os 
costumes internacionais) ou de acordos recíprocos (os tratados internacionais) (BOBBIO, 1987, p. 101).

Ante tal contexto, pode-se afirmar que a soberania dos Estados tem duas faces: uma referente aos limites internos, ou seja, diz respeito às relações entre governantes e governados; e uma face externa, da qual derivam as relações dos Estados entre si. São, portanto, circunstâncias que reclamam uma análise cuidadosa. O Estado tem relações internas com seus cidadãos, nas quais os que detêm o monopólio da força legítima têm o poder de impor aos seus destinatários o cumprimento das normas. Todavia, nas relações entre Estados soberanos, ou seja, no âmbito das relações internacionais, a relação entre Estados é do tipo contratual "cuja força vinculatória depende exclusivamente do princípio de reciprocidade" (BOBBIO, 2006, p. 223).

Na formação do Estado moderno, Bobbio (1987, p. 101-102) ressalta a existência de correspondência entre os limites externo e interno, de forma que quanto mais um Estado é forte no seu interior, mais será no seu exterior, de forma que "o processo de unificação em relação ao interior corresponde um processo de emancipação em relação ao exterior". Assim sendo, quanto mais um Estado conseguir vincular-se aos seus súditos, mais ele conseguirá tornarse independente dos outros Estados. Bobbio (2006, p. 221) afirma que os manuais de direito público, ao enfrentarem o problema da soberania, começam afirmando que "a soberania tem dois aspectos, um interno e outro externo. A distinção entre soberania interna e soberania externa é por assim dizer o $a b c$ da teoria do Estado".

Quando analisa o desenvolvimento da democracia sob a perspectiva das promessas não cumpridas, Bobbio (2009a, p. 188) o fez justamente refletindo sobre os obstáculos internos. Mas posteriormente vai além, e se propõe a pensar os obstáculos externos, ou seja, "aqueles que um regime democrático encontra na medida em que faz parte da sociedade internacional, que é por si mesma essencialmente anômica e da qual fazem parte Estados não democráticos". Ele ainda comenta as previsões de Gino Germani, Jean-François Revel e Richard Falk sobre a relação entre democracia e sistema internacional, afirmando que o primeiro, Gino Germani, apresentava as causas externas como ponto de maior vulnerabilidade da democracia ante as autocracias. Já Falk considerava que a simples existência de armas nucleares seria um contraponto ao ordenamento democrático, enquanto François Revel, na obra "Como terminam as democracias", alertava que as democracias estavam fadadas a desaparecer diante do totalitarismo.

Segundo Revel (1984, p. 7), a democracia moderna era somente "um acidente na história", sendo um tipo de organização política que se volta determinadamente para o seu interior, ignorando ou mesmo negando as 
ameaças de que é objeto. A esses inimigos internos, inclusive, a democracia assegura os seus lugares por meio das suas próprias leis, de forma que os inimigos jogam "uma partida fácil", pois exploram o direito de discordar, "inerente à própria democracia". Todavia, entendo que a existência de dissensões não é uma falha que enfraquece a democracia ou que beneficia os jogadores opositores. Ao contrário, as divergências reforçam a democracia, desde que visem construir o consenso. O conflito legítimo não a desnatura, desde que mesmo no dissenso sejam respeitas as "regras do jogo" democrático, dentre estas as que estabelecem quem são os jogadores e quais os movimentos que podem ser feitos.

A propósito, Bobbio afirma que a história havia desmentido Revel, porque exatamente ao contrário do previsto, os Estados totalitários caíram, enquanto o número de Estados democráticos tem aumentado continuamente. Assim, ele constata que "talvez as previsões dos profetas agourentos também acabem agora por não se realizar", de modo que da mesma forma que se repetem as ideias também se reiteram os erros de previsão (BOBBIO, 2009a, p. 190). A ideia de proclamar "o fim da democracia", a propósito, parece ser um fenômeno comum aos períodos de crise, da mesma forma como já foi anunciado o fim da modernidade, do progresso e até mesmo "o fim da história". Segundo Bobbio é apenas uma conjectura, assim como também o é a ideia contrária.

Outro ponto importante é, considerando que a grande parte dos Estados atuais não é democrata, refletir "em que sentido, e porque, a atual sociedade internacional não pode se dizer democrática" (BOBBIO, 2009a, p. 191). Para ilustrar a questão, ele propõe-se à construção de um processo ideal do nascimento de um Estado democrático no qual o ponto de partida é o estado de natureza dos contratualistas dos séculos XVII e XVIII (a guerra permanente) e o de chegada, o estado civil (a paz estável) dando-se a passagem de um para outro "mediante um conjunto de acordos, dos quais o primeiro, ainda que não declarado, tácito ou implícito, é um pacto de não-agressão entre os indivíduos singulares que desejam sair do estado de natureza" (BOBBIO, 2009a, p. 191). Neste ponto, ele trata do pacto de não agressão (em sentido positivo e negativo) e da passagem do estado polêmico (relativo à guerra, ao modo agressivo de lutar pelos próprios interesses) ao estado agonístico (em que esta luta se dá a partir de regras, a "arte da luta"). Aqui, portanto, Bobbio aproxima-se da conjectura kantiana (e contratualista) que considerava que tanto os indivíduos quanto os Estados deveriam sair do estado natural em que se encontravam, para entrarem no estado legal. Segundo Kant ( $A$ doutrina do direito), a sociedade internacional estava ainda no estado de natureza (ou de guerra), de forma que, por não haver um poder comum que regulasse a relação entre os Estados, prevalecia entre estes o (injusto) direito do mais forte ${ }^{17}$ (MELO, 2010). 
No entanto, vivemos num universo em que um pacto de não agressão universalmente aceito não é possível, e ante a sua ineficácia, a violência entre os Estados é sempre uma possibilidade. Quando ocorre uma agressão, ainda que seja condenável, na maioria das vezes é impunível, e sendo impune "o princípio supremo em que se inspira a conduta de um Estado é o da sobrevivência, exatamente como ocorre no estado de natureza segundo a hipótese hobbesiana" (BOBBIO, 2009a, p. 202). Pode-se afirmar, portanto, que da perspectiva das relações internacionais, ainda estaríamos num estado de natureza. Assim, precisamos de um monopólio do poder mundial, assim como existe um monopólio da força legítima no interior dos Estados democráticos.

Zolo (2011) afirma que o pacifismo jurídico de Bobbio tem raízes ao mesmo tempo em Kant e em Hobbes, de modo que se pode afirmar que ele desenvolveu o contratualismo de Hobbes "em chave kantiana" (atribuindo a ele um alcance universal e cosmopolita), bem como interpretou Kant "em chave hobbesiana", ao atribuir ao federalismo kantiano o significado do projeto de "superação da soberania dos Estados nacionais e de formação de um Estado mundial ${ }^{18 " . ~ U m a ~ q u e s t a ̃ o ~ i m p o r t a n t e ~ q u e ~ e s t a ~ t e s e ~ b o b b i a n a ~ d e ~ u m a ~ F e d e r a c ̧ a ̃ o ~}$ Mundial de Estados coloca é até que ponto esta autoridade não é uma ameaça para a democracia, pois pressupõe uma grande concentração de poder nas mãos de poucos. Por isso, é imprescindível definir melhor a proposta de Bobbio: a ideia central é a de que o processo de constituição de um Estado mundial implica, como condição necessária, que haja um número sempre crescente de Estados que se tornem democráticos. Assim, são condições necessárias para consolidação do pacto democrático

\footnotetext{
a) que o poder soberano, por quem quer que seja exercido [...] não se estenda sobre todas as liberdades e todos os poderes que indivíduos e grupos possuem no estado de natureza e, portanto, respeite aquelas liberdades e aqueles poderes que são considerados - justamente por este seu caráter de inatacabilidade - direitos naturais e enquanto tais não são nem suprimíveis nem restringíveis; b) que sejam estabelecidas regras para as decisões coletivas [...] de modo a permitir que tais decisões coletivas sejam tomadas com a máxima participação e o máximo consenso dos próprios contraentes (BOBBIO, 2000, p. 195-196).
}

Ponto marcante nesta discussão é quando o próprio Bobbio (2009a) assinala que o sistema internacional democrático é uma esperança, devendo ser admitida apenas como uma inspiração, na medida em que é perceptível a ineficácia atual dos pactos de não agressão universal entre os Estados. Esta é uma conjectura inspirada pela ideia de paz perpétua e, como convém a uma ideia da razão pura, a uma conjectura não verificável, que só pode ser viável, na prática, como uma ideia reguladora. Segundo o idealismo transcendental kantiano, o fim para garantir a paz perpétua seria, no âmbito interno dos Estados, 
a criação da República e no âmbito externo dos Estados, a realização do direito cosmopolita.

O alerta de Bobbio é no sentido que a existência de uma sociedade internacional completamente democratizada faz pressupor que todos os Estados que fazem parte da sua composição sejam também democráticos. Assim, "a realização de um processo é obstaculizada pela não-realização do outro". Apesar disto, ele conclui que tem aumentado o número de Estados democráticos e, ainda, que "o processo para a democratização da sociedade internacional já se iniciou", o que o permite pensar que estes processos aparentemente antagônicos se fortaleçam, transformando a atual esperança, em previsão. A própria existência de Estados independentes faz pressupor a necessidade de um direito que regule as relações entre eles (BOBBIO, 2000, p. 207).

\section{Considerações finais}

Segundo Bobbio (2003, p. 39), no período que se iniciou no pós Segunda Guerra e que trouxe consigo o fim do fascismo, eram dois os problemas fundamentais, e estritamente conexos, da humanidade: o ordenamento democrático dentro do próprio país e o ordenamento pacífico nas relações entre a Itália e o resto do mundo. Conforme menciona Lafer (2013, p. 61) essas reflexões de Bobbio "têm como raiz a preocupação de eliminar, ou limitar ao máximo, a violência como meio para resolver os conflitos entre indivíduos e grupos dentro de um Estado e nas relações entre os Estados". Ou seja, o nexo interno e o externo, de modo que "o estudo das alternativas à violência no plano internacional ajusta-se coerentemente, na obra de Bobbio, à crítica da violência no plano interno" (LAFER, 2013, p. 61).

Mesmo imbuído na atmosfera cosmopolita, Bobbio não ignorava que a relação estabelecida entre Estados soberanos trazem em si uma tensão latente e potencial, bem como acreditava que quanto mais forte fosse a relação do Estado com os seus próprios cidadãos (ou seja, no âmbito interno), mais forte este mesmo Estado seria no âmbito das relações com outros Estados. E, apesar de declarar que não pretendia fazer apostas para o futuro, Bobbio (2009a) afirmava que era inegável perceber que as democracias existentes "não apenas sobreviveram, como novas democracias apareceram ou reapareceram ali onde jamais haviam existido ou haviam sido eliminadas por ditaduras políticas ou militares". Ele acreditava, inclusive, não ser temerário afirmar que a contemporaneidade poderia ser chamada de "a era das democracias".

A partir desta perspectiva, e embora reconhecesse que se encontrava dividido entre a esperança e a comoção realista dos dias atuais, ele apostava na 
democracia e afirmava que sua utopia era a de uma democracia internacional, que conseguisse resolver os conflitos entre os Estados através do debate e sem violência recíproca (BOBBIO, 1994). Neste sentido, as suas formulações sobre as relações internacionais de um sistema de Estados democráticos, inclusive como garantia do funcionamento das democracias no âmbito interno dos Estados, apontam para o seu ideal de um estado de paz como caminho possível. A democracia internacional, que Bobbio defende como a submissão de todos os Estados a uma nova ordem democrática, seria capaz de resolver os conflitos entre os Estados sem recorrer à violência, fundando uma paz estável e fundada no livre consentimento entre estes mesmos Estados.

Assim, apesar de admitir os tropeços e tratar da internacionalização da democracia como uma conjectura, Bobbio manteve viva a sua confiança na democracia como a melhor forma de governo, tanto no interior dos Estados, quanto na sua expansão nas relações internacionais. Somente assim o ideal kantiano da paz perpétua poderia ser perseguido e o "futuro da democracia" avançaria para um processo de expansão e democratização das relações internacionais, entre Estados igualmente democráticos.

Quando concluiu seu texto ensaio Democracia e sistema internacional Bobbio afirmou que aquele, de fato, era uma conjectura inspirada na ideia da Paz Perpétua kantiana, relembrando que esta paz perpétua ${ }^{19}$ só seria possível entre Estados que tivessem a mesma forma de governo e, ainda, que esta forma de governo fosse a republicana (BOBBIO, 2000). Ocorre que, se considerarmos que nas relações internacionais atuais estaríamos vivenciando um círculo vicioso, em que os Estados somente poderão se tornar Estados democráticos em uma sociedade internacional completamente democratizada restam ainda dúvidas sobre até que ponto esta proposta de democratização se coaduna com a própria democracia. E explico: entendo que a democracia não deve ser imposta de modo artificial, sem considerar as particularidades e características de cada Estado. Até mesmo esta visível disseminação da democracia chega a ser preocupante quando se pensa que, não obstante Estados democráticos não tenham realizado guerras entre si, o fizeram em relação a outros Estados, muitas vezes sob argumentos que respaldam a necessidade de tornar a democracia universal.

Parece-me, por vezes, que estas são justificativas bastante similares àquelas dos discursos de algumas "intervenções humanitárias", que agindo supostamente em prol dos direitos humanos, de fato atentam veementemente contra os próprios direitos humanos. Sempre é preciso cautela ante os defensores de qualquer nova ordem mundial que tenha a pretensão de servir e ser igualmente positiva para todos. E neste sentido, concordo com Hobsbawm (2007, p. 116) quando este afirma que esta é uma visão perigosa, quixotesca e 
subestima a própria complexidade do mundo. Nada me parece mais antidemocrático que estabelecer que a democracia é um modelo que pode (ou deve) ser imposta em qualquer lugar, cultura ou circunstância, ignorando que ela não serve apenas como um padrão, sendo iguais em qualquer parte do mundo, como o são os postos de gasolina e os shopping centeres.

Deste modo, igualmente entendo que Bobbio não defenderia uma exportação da democracia por meios violentos como ocorreu, por exemplo, no Afeganistão e no Iraque. As suas apostas eram num processo gradual de expansão dos Estados democráticos que poderia, com todas as ambiguidades, os avanços e os retrocessos típicos da história humana - levar para a realização do ideal regulador de um Estado Mundial ou de uma Federação Mundial que garantisse a paz. E assim, ele confirmava as apostas que atribuiu, seguindo a inspiração kelseniana, ao direito internacional como um fim necessário e indispensável da democracia. Não seria possível a sobrevivência, em longo prazo, dos Estados democráticos, num contexto de outros Estados não democráticos, autocráticos, autoritários, ditatoriais. Por isso, o cosmopolitismo é visto por ele como o cumprimento necessário do sistema jurídico e político, sempre, porém, com o idealismo da vontade e o pessimismo da razão ou, em outras palavras, considerando os contrastes entre os ideais e a bruta matéria.

\section{Referências}

ANDERSON, P. Afinidades seletivas. São Paulo: Boitempo Editorial, 2002. p. 197-242

BOBBIO, N. A era dos direitos. Nova Edição. Rio de Janeiro: Elsevier, 2004.

. Estado, governo e sociedade: para uma teoria geral da política. $14^{\mathrm{a}}$ ed. Rio de Janeiro: Paz e Terra, 1987.

. Liberalismo e democracia. 6a ed. São Paulo: Brasiliense, 2005.

Nem com Marx, nem contra Marx. São Paulo: Editora UNESP, 2006.

O futuro da democracia: uma defesa das regras do jogo. $11^{a}$ ed. São

Paulo: Paz e Terra, 2009a.

O Terceiro Ausente: ensaios e discursos sobre a paz e a guerra. São

Paulo: Manole, 2009b.

2003.

. Os problemas da guerra e as vias da paz. São Paulo: Editora UNESP,

. Politica e cultura. Turim: Einaudi, 1955.

Qual Socialismo? Debate sobre uma alternativa. $2^{a}$ ed. Rio de Janeiro:

Paz e Terra, 1983.

. Teoria Geral da Política: A Filosofia Política e as Lições dos Clássicos. 
$12^{\mathrm{a}}$ ed. Rio de Janeiro: Elsevier, 2000.

BOBBIO,N. BRESSER-PEREIRA, L. C. Bobbio defende o 'compromisso' entre liberalismo e socialismo. [online]. 1994. Disponível em: <http://www.bresserpereira.org.br/articles/94.5.12. Entrevista-bobbio.pdf >. Acesso em: 21 ago. 2011.

BRANDÃO, A. Bobbio na história das ideias democráticas. Lua Nova [online]. 2006, n. 68, pp. 123-145. Disponível em: <http://www.scielo.br/pdf/ln/n68/a05n68.pdf>. Acesso em: 21 ago. 2011. . Bobbio: um grande ensaísta, não um tratadista. In Studium. Revista de Filosofia, Ano 11, no 21 e 22, 2008, pp. 09-26.

CAYGILL, H. Dicionário Kant. Rio de Janeiro: Jorge Zahar, 2000.

HOBSBAWM, E. Globalização, democracia e terrorismo. $3^{a}$ ed. São Paulo: Companhia das Letras, 2007.

KANT, I. A Paz Perpétua e Outros Opúsculos. Lisboa, Edições 70, 1989.

LAFER, C. Norberto Bobbio: trajetória e obra. São Paulo: Perspectiva, 2013.

. Prefácio à Edição Brasileira. In BOBBIO, N. O Terceiro Ausente: ensaios

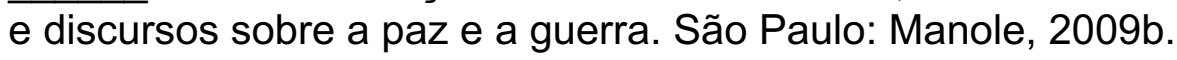

MELO, C. C. Cosmopolitismo (verbete). In BARRETO, V. P. (Org.). Dicionário De Filosofia Política. São Leopoldo, Unisinos, 2010.

REVEL, J.F. Como terminam as democracias. São Paulo: DIFEL, 1984.

ROCHA, A. S. E. Bobbio: da correlação liberdade-igualdade ao imperativo de "igual liberdade". In TOSI, G. (Org.). Norberto Bobbio: Democracia, direitos humanos, paz e guerra. João Pessoa, Editora UFPB, 2011.

SALGADO, J. C. A Ideia de justiça em Kant: seu fundamento na liberdade e na igualdade. Belo Horizonte: UFMG, 1986.

TERRA, R. R. A Política Tensa: Ideia e realidade na filosofia da história de Kant. São Paulo: lluminuras, 1995.

TOSI, G. A democracia como forma mista de governo em Norberto Bobbio. In TOSI, G. (Org.). Norberto Bobbio: Democracia, direitos humanos, guerra e paz. João Pessoa, Editora UFPB, 2011, p. 223-248.

ZOLO, D. Luzes e sombras do "pacifismo jurídico" de Norberto Bobbio. In TOSI, G. (Org.). Norberto Bobbio: Democracia, direitos humanos, guerra e paz. João Pessoa, Editora UFPB, 2011, p. 321-334.

. Rumo a um ocaso global? Os direitos humanos, o medo, a guerra. Florianópolis: Editora Conceito, 2011.

\footnotetext{
${ }^{1}$ Este artigo é uma versão ligeiramente modificada da minha dissertação de Mestrado Norberto Bobbio e a questão democrática: Encruzilhadas e perspectivas, orientada pelo Professor Doutor Giuseppe Tosi e defendida no Mestrado em Filosofia da Universidade Federal da Paraíba, em setembro de 2011.

2 A esta tríade "direitos humanos, democracia e paz", Acílio Rocha (2011) vai chamar de "círculo virtuoso", por serem referências essenciais para uma sociedade mais justa. Já Brandão (2011) o denomina como
} 
"tripé temático fundamental" da reflexão política de Bobbio, embora entenda que a democracia tem lugar de destaque entre os três.

${ }^{3}$ O futuro da democracia é o livro mais famoso de Bobbio sobre o tema democracia. Segundo Brandão (2008, p 15) este "foi traduzido para inúmeras línguas, desde o português até o servo-croata, e tem por conteúdo uma 'Premissa' e sete artigos, todos da década de 80, exceto 'Democracia representativa e democracia direta', que é de 1978. Os mais destacados artigos do livro são 'O futuro da democracia', 'democracia representativa e democracia direta', 'A democracia e o poder invisível', 'Contrato e contratualismo no debate atual', além de 'Os vínculos da democracia'. Este último ensaio discrepa um pouco da maior parte do livro por conter algumas tiradas marcadamente elitistas".

${ }^{4}$ Embora a precisão das suas análises, a quantidade e convergência de elaborações textuais e a riqueza descritiva dos conceitos elaborados apontem para a formação de uma teoria, há questionamentos sobre se se pode falar em uma teoria da democracia de Bobbio. De fato, a forma de escrever adotada por ele (sobretudo textos, artigos, ensaios, conferências) sinaliza a dificuldade de uma visão do conjunto da sua obra e das suas ideias de forma sistematizada, ou seja, com um grau maior de organicidade. Mas, ao mesmo tempo não há como negar três passos importantes para a formação de uma teoria que são visíveis na obra de Bobbio: ele prezou pela leitura dos clássicos da tradição, apresentou críticas a esta mesma tradição, e formulou propostas para muitas das questões mais relevantes. Ocorre que, para que uma investigação no nível de discussão sobre este ponto na obra de Bobbio fosse elaborada de forma precisa, seria necessário antes de tudo refletir sobre o que entendemos por "teoria". Entretanto, esta discussão recairia inevitavelmente numa "disputa teórica sobre a natureza das teorias", ou sobre as teorias das teorias, como o próprio Bobbio (2006, p. 210) alertou quando tratava da (in)existência de uma teoria do direito em Marx. Assim, não adentrarei nesta discussão, mas considerando o sentido kantiano de teoria, como sendo um conjunto de regras práticas pensadas como princípios numa certa universalidade (KANT, 2009, p. 59), optei por, neste artigo, tratar o conjunto de ideias de Bobbio como a sua concepção (ao invés de teoria) da democracia.

${ }^{5}$ Tosi (2011) defende que Bobbio tem uma concepção a que chama de "mista" da democracia, sendo esta composta por três dos elementos: a democracia representativa, a democracia participativa e a democracia como competição entre elites. Yturbe (2011), por sua vez, entende que a concepção bobbiana de democracia é processual, devendo ser compreendida como um método, um sistema de regras para se tomar decisões coletivas. É, portanto, uma concepção política, formal e, ainda, representativa, posto que as decisões são tomadas por representantes dos cidadãos, eleitos através do voto.

6 Bobbio reconhece que "se não tivéssemos aprendido com o marxismo a ver a história a partir da perspectiva dos oprimidos, ganhando uma nova e imensa perspectiva sobre o mundo humano, não teríamos sido salvos Tradução nossa: [lo sono convinto che se non avessimo imparato dal marxismo a veder la storia dal punto di vista degli oppressi, guadagnando una nuova immensa prospettiva sul mondo umano, non ci saremmo salvati].

7 Em italiano, o termo "liberalismo" se refere ao liberalismo político enquanto o termo "liberismo" designa o liberalismo econômico. Na Itália, o liberalismo foi um fenômeno diferenciado dentro do contexto da Europa, posto que, ao contrário do ocorrido na Alemanha, "a unificação nacional foi obtida não sobre o cadáver, mas sob a própria bandeira do liberalismo" (ANDERSON, 2002, p. 210).

${ }^{8}$ A concepção ética de democracia é a concepção de um Bobbio mais jovem, mais otimista, que dava mais relevância à participação da cidadania e acreditava na democracia como uma forma de governo capaz de educar os cidadãos para a liberdade. A concepção procedimental é a concepção de um Bobbio mais maduro, mais realista, ora mais ora menos desencantado com as possibilidades da democracia, ora mais ora menos normativo, que acreditava na democracia desprovida de sua natureza ética, apenas como um procedimento (BRANDÃO, 2011).

${ }^{9}$ Vale observar que esta concepção chamada de procedimentalista é adotada no século XX pela maioria dos estudiosos liberais da política, como Schumpeter, Kelsen, Popper e Hayek, embora estes pertençam a tendências políticas diferentes.

${ }^{10}$ Deve-se ter em mente que "o mais forte argumento adotado pelos reacionários de todos os países contra os direitos do homem, particularmente contra os direitos sociais, não é a sua falta de fundamento, mas a sua inexequibilidade". Portanto, não há que se falar em proteção de direitos fundamentais sem recursos ou, ainda pior, sem exigibilidade (BOBBIO, 2004, p. 23). A obra do legislador não está completa, conforme 
alertou Benjamin Constant (1985), quando simplesmente torna os cidadãos tranquilos, devendo esta dar ao povo tanto o desejo quanto a faculdade de executar seus direitos, sua participação no exercício do poder. ${ }^{11}$ Quando tenta compreender a definição de direito kantiana contrapondo os critérios de distinção entre o direito e a moral, Bobbio (1995, p. 71) se indaga sobre qual o valor daquela definição? "ela se refere a que o direito é ou a o que o direito deve ser?" Então Bobbio recorre a terminologia moderna para se perguntar se Kant define o conceito de direito ou se na verdade ele se refere a ideia de direito. Parece-me claro que a resposta caminha no sentido da segunda alternativa, preocupando-se em refletir sobre como o direito deve ser ao invés de meramente compreender o direito é enquanto conceito.

12 Por metáfora aproximativa Bobbio (2003, p. 53) entende que assim o são todas as metáforas, posto que "a história humana é demasiado complicada para que a sua apresentação possa ser abarcada por uma imagem; ou é tão complicada que, não podendo expô-la por conceitos, devemos contentar-nos com metáforas aproximativas (mas nesse caso devemos estar bem conscientes da diferença que passa entre uma imagem e um conceito)".

13 Tratando do tema "Kant e a Revolução Francesa", o ponto central que Bobbio (2004, p. 124) eleva a discussão é que a disposição moral da espécie humana "se manifesta na afirmação do direito - um direito natural - que tem um povo a não ser impedido por outras forças de se dar a Constituição civil que creia ser boa". Para Kant, essa Constituição tem que ser republicana.

${ }^{14}$ Bobbio (2004) não ignorava as outras perspectivas que poderiam ser adotadas para tratar da questão dos direitos do homem, indicando, dentre elas, a filosófica, a histórica, a política, a ética e a jurídica, mas optou neste seu discurso pela filosofia da história, embora a considerasse como desacreditada no ambiente cultural italiano, além de ser arriscada (e talvez até pretensiosa) porque ela poderia englobar todas as outras.

${ }^{15}$ Sobre o progresso, nos moldes kantianos, Bobbio (2004, p. 61) afirma que, para Kant, o progresso não era necessário, mas apenas possível. E ainda que Kant "criticava os 'políticos' por não terem confiança na virtude e na força da motivação moral, bem como por viverem repetindo que 'o mundo foi sempre assim como o vemos hoje'. Kant afirmava que, com essa atitude, tais 'políticos' faziam com que o objeto de sua previsão - ou seja, a imobilidade e a monótona repetitividade da história - se realizasse efetivamente. Desse modo, retardavam propositalmente os meios que poderiam assegurar o progresso para o melhor. Com relação às grandes aspirações dos homens de boa vontade, já estamos demasiadamente atrasados. Busquemos não aumentar esse atraso com nossa incredulidade, com nossa indolência, com nosso ceticismo. Não temos muito tempo a perder".

${ }^{16}$ Melo (2010, p. 130) afirma que o período pós Segunda Guerra Mundial se revelou como propício para a "consolidação institucional dos princípios políticos do ideal cosmopolita. A ruptura civilizacional provocada pelos conflitos mundiais propiciou a possível transição do direito internacional para o direito cosmopolita".

${ }^{17}$ Deste modo, e diante das dificuldades de estabelecer o projeto da paz perpétua, "Kant aposta no direito cosmopolita para o fortalecimento das instituições baseadas nos princípios políticos desse projeto" (MELO, 2010, p. 129)

${ }_{18}$ Zolo (2011), entretanto, afirma que o próprio Bobbio havia reconhecido o perigo que representaria a concentração do poder internacional nas mãos das grandes potências, de modo que nunca mais ele viria a usar as expressões "governo mundial" ou "Estado mundial".

${ }^{19}$ Em texto posterior (2009a) Bobbio cita os requisitos para uma paz mais estável (ao invés de usar a palavra "perpétua") no mundo. Ele afirma que embora tenha em mente a obra de Kant, não se atreveria a usar o termo "perpétua" nesta questão. 